\title{
Effect of water stress and Coffee ringspot virus on coffee leaf temperature and its relationship with Brevipalpus yothersi population
}

\author{
Matheus Mancini Porfírio Nunes ${ }^{1}$ (D), Jaqueline Franciosi Della Vechia ${ }^{1}$ (D), Daniel Júnior de Andrade ${ }^{1}$ (iD
}

${ }^{1}$ Universidade Estadual Paulista "Júlio de Mesquita Filho"/UNESP, Faculdade de Ciências Agrárias e Veterinárias/FCAV, Jaboticabal, SP, Brasil

Contact authors: matheus.mpn@gmail.com, jaque_dellavechia@hotmail.com, daniel.andrade@unesp.br

Received in January 8, 2020 and approved October 28, 2020

\begin{abstract}
The Brevipalpus yothersi Baker mite is a vector of Coffee ringspot virus (CoRSV), the causing agent of coffee ringspot disease. Knowing the mite-host interaction and the variables that improve the development of the mite are important in order to manage the disease. The aim of this work was to study the relationships of cause and effect between water availability and leaf temperature on population fluctuation of $B$. yothersi on coffee plants Coffea arabica L. Inside a greenhouse, plants under four levels of field capacity: $25,40,55$ and $70 \%$ were arranged in two groups: (1) infestation of viruliferous $B$. yothersi with CoRSV and (2) no mite infestation. Following the transfer of mites to coffee plants, leaf temperature was measured daily in order to calculate the Daily Water Stress Index (DWSI). At the end of this experiment, the mites present on coffee plants were quantified and leaf samples were collected for leaf nitrogen content measurements. It was found that plants infested with $B$. yothersi indicated higher values of DWSI and lower levels of leaf nitrogen content when compared to non-infested plants. Furthermore, plants on higher water availability revealed higher populations of $B$. yothersi.
\end{abstract}

Key words: Coffee ringspot; Coffea arabica; Vegetal stress; Nutrient.

\section{INTRODUCTION}

Coffee is one of the most consumed beverages in the world, reaching a worldwide consumption of 150 to 160 million bags in the years 2014 to 2017 (International Coffe Organisation, ICO, 2019). In Brazil, coffee growing is the most employed agribusiness sector in the country, generating more than 8 million jobs, mainly for the production of arabica coffee Coffea arabica L. (Ministério da Agricultura, Pecuária e Abastecimento, MAPA, 2018; Companhia Nacional de Abastecimento, CONAB, 2019a). Brazil is the largest producer and exporter of coffee in the world, being responsible for the production of around 45 million processed bags in 2017 (CONAB, 2019b), which represented 29.1\% of world production (Food and Agriculture Organization Statistics Division, FAO, 2019).

Despite the significant production of coffee in Brazil, coffee plants has several phytosanitary problems that negatively impact the profitability of the crop. Among the diseases, there is the coffee ringspot, caused by the virus Coffee ringspot virus (CoRSV). The coffee ringspot was described in 1938 by Bitancourt, it was found first in plants located in Caçapava-SP, Brazil (Boari, 2011) and later found in other regions of Brazil (Branquinho et al., 1988; Figueira et al., 1995; Rodrigues; Nogueira, 2001; Kitajima; Chagas, 2009).

Coffee ringspot virus infection results in crop yield losses. Virus-infected coffee fruits have changes in their metabolism, which may lead to a decrease in grain weight and negatively affect beverage quality. CoRSV causes irregular fruit ripening, causing reduced sugar levels and increased butyric acid concentration, which considerably affects beverage quality standards (Reis; Chagas, 2001; Boari, 2011). On the leaves, symptoms are concentric ring-shaped chlorotic spots, while yellowish spots on the fruits (Chagas, 1973). In addition, CoRSV infection can cause leaf and fruit fall (Figueira et al., 1995; Rodrigues et al., 2002).

The Brevipalpus phoenicis mite (Geijskes) (Acari: Tenuipalpidae) until 2015 was considered as the only vector of CoRSV, being also pointed as transmitting numerous viruses to other plants, including the main viral disease of the Brazilian citrus, the citrus leprosis (Citrus leprosis virus - CiLV) (Bastianel et al., 2010; Kitajima; Rodrigues; Freitas-Astúa, 2010) and the passion fruit green spot disease (Moraes et al., 2006). However, Beard et al. (2015) found that this species is a morphospecies complex. Few studies have confirmed the correspondence between the new classified species and the transmitted viruses, however, it is known that CoRSV can be transmitted by Brevipalpus yothersi Baker (Acari: Tenuipalpidae) (Nunes et al., 2018a) and Brevipalpus papayensis Baker mites (Acari: Tenuipalpidae) (Nunes et al., 2018b). Brevipalpus yothersi has also been confirmed as a vector for cytoplasmic citrus leprosis viruses (CiLV-C and CiLV-C2) (Roy et al., 2015; Ramos-González et al., 2016), Clerodendrum chlorotic spot virus (ClCSV) (Ramos-González et al., 2018) and it is probably also a vector of Citrus chlorotic spot virus (CiCSV) (Chabi-Jesus et al., 2018).

Since disease control is mainly performed by vector control, the concern and the need for control of the mite has increased, aiming to avoid economic, environmental and social damages (Boari, 2011). However, in order to adopt appropriate 
vector control techniques, it is essential to know the host-pest interactions under different environmental variables, such as water availability.

Under normal conditions, the leaf temperature of the plants is below the air temperature (Machado et al., 1994), however, research has shown that plants under stress, especially abiotic stress, have higher leaf temperatures than air (Nogueira et al., 1998). This condition can affect interaction with pests. Mattson and Haack (1987) found that plants under water stress presented higher leaf temperatures than leaves of nonstressed plants, yet plants under water stress had larger insect and phytophagous mite populations. The authors attributed this result to the increased body temperature of arthropods, which allows them to have a better optimal condition for their development and reproduction.

Andrade et al. (2008) observed that plants in water stress conditions presented higher leaf temperatures than the environment and largest populations of B. phoenicis senso latu than plants in optimal conditions. In addition, experimental evidence has shown that stressed plants, due to higher leaf surface temperatures, have altered their nutritional qualities such as increased free amino acids available, leading to increased herbivorous growth rates that help explain pest outbreaks in periods prolonged drought (White, 1984).

Given the importance of controlling the coffee ringspot, it is important to understand the relationships between $B$. yothersi and its hosts. In order to broaden the knowledge about the pest-host relationship, this study aimed to study the cause-effect relationships between water availability and leaf temperature on $B$. yothersi population fluctuation in coffee plants.

\section{MATERIAL AND METHODS}

\subsection{Mites}

The initial colony of $B$. yothersi was established from specimens collected on symptomatic coffee plants from a coffee orchard, located at Agência Paulista de Tecnologia dos Agronegócios at Pindorama - SP (APTA) (21 ${ }^{\circ} 11^{\prime} 52$ ' S; $\left.48^{\circ} 55^{\prime} 15^{\prime} \mathrm{W}\right)$. The mites were morphologically identified and confirmed the species $B$. yothersi by scanning electron microscopy.

Brevipalpus yothersi mites were maintained on pesticide-free coffee leaves ( $C$. arabica), and with the presence of coffee ringspot symptoms for seven days. For this purpose, coffee leaves were placed adaxial side up on a $0.01 \mathrm{~m}$ thick foam and hydrophilic cotton soaked in water to maintain leaf turgor and surrounded by hydrophilic cotton to prevent mite escape. The plates were kept in a room under controlled conditions $\left(25 \pm 1{ }^{\circ} \mathrm{C}, 60 \pm 5 \% \mathrm{RH}\right.$, and $12: 12 \mathrm{~h}$ LD cycle).

\subsection{Field capacity determination}

Were used pots containing $5 \mathrm{~kg}$ of soil, which was nutritionally analyzed. Soil nutrients were corrected as needed for the maintenance of coffee plants. To determine the field capacity of the soil contained in the pots, the weighing technique was used (Medina; Machado; Pinto, 1998). This technique consists of drying the soil of the pots outdoors until it reaches a constant weight. Subsequently, the soil was saturated with water and, after complete drainage, was weighed again to obtain the wet weight. From the difference between wet weight and dry weight, it was possible to determine the amount of water to maintain the desired field capacity.

Pot weighing was performed three times a week, determining the amount of water to be added to maintain the soil at the pre-established field capacity. To determine the weight of each pot to maintain the desired field capacity, the following equations were used:

Psat $-P d r y=X$

$X * C C=Y$

$P d r y+Y=P i$

where:

Psat - weight of pot with soil saturated with water

$P d r y$ - dry pot weight

$X$ - amount of water absorbed by the soil

$C C$ - soil field capacity

$Y$ - amount of water related to field capacity

$P i$ - ideal weight

After the determination of field capacity, each pot was labeled with the ideal weight and pre-established field capacity information and kept in a greenhouse.

\subsection{Coffee plants}

The coffee plants used in the experiment were $C$. arabica 'Mundo Novo', approximately eight months old, planted in plastic bags filled with substrate. These plants were transplanted to the pots mentioned in the previous item and kept in a greenhouse.

\subsection{Experimental design}

In the greenhouse the plants were submitted to four levels of field capacity (FC): 25, 40, 55 e 70\% and were arranged in two groups, (1) plants infected with $B$. yothersi viruliferous for CoRSV and (2) control - plants without mites. The experimental design was in blocks with randomized plots, in a factorial scheme consisting of the factors: (A) field capacity $(25,40,55 \mathrm{e}$ $70 \%$ ), and (B) with or without mites. The combination of factors and their respective levels $(4 \times 2)$ resulted in 8 treatments, which were repeated 7 times, totaling 56 pots. 


\subsection{Mite transfer}

After 45 days of transplanting, 30 adult $B$. yothersi females were transferred to each plant with the aid of a brush and a 40-fold stereoscope. An entomological glue barrier was applied to the base of the plant stem to prevent $B$. yothersi from escaping while preventing access by predators.

\subsection{Determination of leaf temperature}

After mite transfer, leaf temperature measurements were started with a digital infrared thermometer model SCAN TEMP / ST-700. Temperature assessments were performed daily between 12 and 13 hours, time near solar noon. Leaf temperature was measurements during 28 days.

In order to standardize the measurements, the third leaf from the apex of each pot was marked with tape, and the pots were always positioned in the same position, ensuring the leaves were in the same direction. To obtain the reference temperature (air temperature), a mercury thermometer was placed inside the greenhouse one meter above the plants of the experiment.

\subsection{Daily Water Stress Index}

At the end of the leaf temperature measurements the Daily Water Stress Index (DWSI) was calculated, subtracting the leaf temperature value with a reference (mercury thermometer), according to the following equation (Jackson, 1982; Fernandes; Turco, 2003):

$D W S I=T f-T r$

where:

$D W S I$ - daily water stress index of plants, ${ }^{\circ} \mathrm{C}$;

$T f$ - average leaf temperature of treatment, ${ }^{\circ} \mathrm{C}$;

$\mathrm{Tr}$ - greenhouse temperature, ${ }^{\circ} \mathrm{C}$.

\subsection{Brevipalpus yothersi quantification}

Twenty-eight days after mites transferring, the branches and leaves of each plant were removed and with the aid of a sweeping machine (Oliveira, 1983), the mites were removed from the plant structures. Under stereoscopic microscopy, the mites were counted.

\subsection{Leaf analysis}

After mite counting, the third and fourth leaves were collected from the apex of coffee plants of four plants per treatment. The leaves were washed in neutral detergent deionized water and placed in oven drying paper bags at $65^{\circ} \mathrm{C}$ for 72 hours. They were sent to the Laboratório Athenas Consultoria Agrícola to determine the nitrogen content.

\subsection{Data analysis}

Brevipalpus yothersi population, DWSI, and nitrogen content data were subjected to analysis of variance by the $\mathrm{F}$ test and means compared by the Tukey test at $5 \%$ probability. For such analyzes, the AgroEstat 1.0 software was used (Barbosa; Maldonado Junior, 2015). The results of the analysis of variance for $B$. yothersi population at different field capacities were obtained by transforming the original data into $\operatorname{In}(x+5)$.

\section{RESULTS AND DISCUSSION}

All plants were water stressed during the period of the experiment, since the mean DWSI values were higher than 3 (Table 1). The highest DWSI values were observed for $25 \%$ treatment followed by $70 \%$ field capacity (Table 1). On the other hand, there was no significant interaction between the factors (field capacity and presence of mites) (Table 1). The fact that all plants were hydraulically stressed may be explained by the increased evapotranspiration resulting from the high greenhouse temperatures during the experiment and by the frequency of pot water replacement (3 times per week) insufficient to maintain consistently the desired water conditions. This is evidenced by the high amplitude values of the DWSI measurements. The expected effect would be a decrease in leaf temperature and DWSI with increasing water availability, as demonstrated by Mattson and Haack (1987), Costa, Grant and Chaves (2013) and Costa et al. (2018).

In contrast, the presence of mites increased the DWSI, verified by the leaf temperature increase (Table 1). Gutiérrez and Meinzer (1994) stated that stomatal closure in coffee plants reduces latent heat dissipation by perspiration, directly interfering with leaf temperature, thus the increase in DWSI in B. yothersi mite infested plants greater stomatal closure caused by feeding the mites on the leaves. This also was observed by Fadini, Pallini and Venzon (2004) who found that different pest mites in strawberry caused damage to the leaves, causing closure of the stomata of the plant, aiming to reduce water losses. Similar results were obtained by Andrade et al. (2008), in which citrus plants infested with $B$. phoenicis sensu lato infected by the citrus leprosis virus showed increased DWSI.

Another possible hypothesis of increased DWSI is the presence of the coffee ringspot virus. Although no symptom of coffee ringspot was observed the period in which the mites remained on CoRSV infected leaves prior to the experiment was enough for the mites to acquire the virus (Nunes et al., 2018a). Moreover, Brevipalpus sp. nymph and adult larvae are known to be able to transmit CoRSV virus to coffee plants after a tissue feeding period of 18 to 24 hours (Kitajima; Chagas, 2009). Therefore, it is believed that the virus was present in plants in its latent form. Thus, CoRSV could have affected plant physiological processes at the molecular level, as 
demonstrated by Freitas-Astúa et al. (2007) for the CiLV virus, transmitted by Brevipalpus sp. in citrus plants. Among these processes, the authors found that the increased respiratory rate caused by the virus resulted in increased sweating frequency and leaf temperature.

Table 1: Daily Water Stress Index (DWSI) for plants in different field capacities (Factor $A$ ) and in the presence or absence of Brevipalpus yothersi mites (Factor B).

\begin{tabular}{cc}
\hline Field capacity (A) & DWSI (oC)1 \\
\hline $25 \%$ & $4.09(12.7--7.7) \mathrm{a}$ \\
$40 \%$ & $3.37(12.5--9.6) \mathrm{b}$ \\
$55 \%$ & $3.15(12.3--10.2) \mathrm{b}$ \\
$70 \%$ & $3.54(12.6--8.2) \mathrm{ab}$ \\
Teste F (A) & $30.86^{* *}$ \\
SMD & 0.37 \\
No-infested & $3.03(11.2--10.2) \mathrm{b}$ \\
Infested & $4.04(12.7--7.9) \mathrm{a}$ \\
F test (B) & $4.80^{* *}$ \\
SMD & 0.69 \\
F test (Interaction A x B) & $0.13 \mathrm{~ns}$
\end{tabular}

${ }^{1}$ Averages from 07-09-2014 to 22-10-2014 followed by amplitude values. $\mathrm{SMD}=$ significant minimum difference. Treatments differ significantly at the $1 \%\left({ }^{* *}\right)$ probability level, or non-significant $\left({ }^{\text {ns }}\right)$ by the $\mathrm{F}$ test. Means followed by the same lowercase letter do not differ from each other by Tukey test at $5 \%$ probability.

Plant water availability also interfered with $B$. yothersi population. Plants with higher water availability had the largest population of the mite (Table 2). However, in relation to the number of adult mites, no significant difference was observed between field capacities. There was a significant difference between treatments regarding the number of eggs, larvae and nymphs, in which the plants maintained at $70 \%$ of field capacity presented the highest values (Table 2). The smallest population was accounted for at treatments at $25 \%$ and $40 \%$ of field capacity (Table 2).

This result was opposite to that observed by Andrade et al. (2008), who observed that citrus plants under less favorable water conditions presented more favorable leaf temperature for the development of B. phoenicis s.l. This difference can be mainly explained by the death of tissues in coffee plants kept in the smallest field capacities, affecting the quantity and quality of food available to mites. In addition, leaf fall was observed in the plants under the lowest field capacity. Therefore, it is possible that part of the mite population was on these fallen leaves, contributing to the population reduction in these treatments.

Another possible explanation refers to the higher number of shoots in the plants with the largest amount of water in the soil, mainly observed in the treatments with 55 and $70 \%$ of the field capacity. The larger number of shoots may have favored the feeding of the mites and consequently their reproduction rate. Czermainski et al. (2007) verified that the emission of sprouts in citrus seedlings resulted in an increase of the population of B. phoenicis s.l., especially of larvae and nymphs. Barbosa et al. (2003) attributed the population increase of mites of the family Tenuipalpidae, including $B$. phoenicis s.l. in acerola plants to the increase of the number of shoots. Thus, the increased availability of young tissue in plants under better water conditions may have favored the development of mites. Young tissue cells show greater turgidity, facilitating the feeding of phytophagous mites, reducing their energy expenditure during feeding. Mites puncture plant cells with stylets for extravasation of cell contents for ingestion via mouth opening (Krantz; Walter 2009), requiring minimal cell turgidity.

Table 2: Average number of eggs, larvae, nymphs, adults and total of Brevipalpus yothersi in plants under different field capacities (FC).

\begin{tabular}{cccccc}
\hline FC & Eggs $^{1}$ & Larvae $^{1}$ & Nymphs $^{1,2}$ & Adults $^{1}$ & Total $^{1}$ \\
\hline $25 \%$ & $25.71 \mathrm{~b}$ & $6.14 \mathrm{c}$ & $12,29 \mathrm{~b}$ & $10.00 \mathrm{a}$ & $54.14 \mathrm{~b}$ \\
$40 \%$ & $28.29 \mathrm{ab}$ & $8.71 \mathrm{bc}$ & $15.71 \mathrm{~b}$ & $6.86 \mathrm{a}$ & $59.57 \mathrm{~b}$ \\
$55 \%$ & $43.00 \mathrm{ab}$ & $18.29 \mathrm{ab}$ & $39.71 \mathrm{ab}$ & $10.00 \mathrm{a}$ & $111.00 \mathrm{ab}$ \\
$70 \%$ & $63.71 \mathrm{a}$ & $21.71 \mathrm{a}$ & $52.43 \mathrm{a}$ & $14.57 \mathrm{a}$ & $152.43 \mathrm{a}$ \\
F test & $3.14^{*}$ & $7.25^{* *}$ & $6.76^{* *}$ & $1.02^{\text {ns }}$ & $5.38^{* *}$ \\
C.V. (\%) & 19.02 & 14.15 & 16.77 & 20.31 & 13.93 \\
SMD & 1.00 & 0.58 & 0.82 & 0.78 & 0.90 \\
\hline
\end{tabular}

Original data transformed into $\ln (x+5) .{ }^{1}$ The data presented is the original. ${ }^{2}$ Nymphs (protonymph + deutonymph); C.V. = coefficient of variation; $\mathrm{SMD}=$ significant minimum difference. Averages followed by the same lowercase letter in the column do not differ from each other by the $\mathrm{F}$ test. Treatments differ significantly at the $5 \%\left(^{*}\right)$ or $1 \%\left(^{* *}\right)$ probability level, or not significant $\left({ }^{\mathrm{ns}}\right)$ by the $\mathrm{F}$ test.

Still another explanation for the reduction of mite population in treatments with less water availability would be the possible increase in the production of secondary metabolites produced by plants. As found by Briske and Camp (1982) and Höft, Verpoorte and Beck (1996), the production of alkaloids in plants increases when under water stress conditions, the same occurs for other secondary metabolites such as terpenoids (Lokar et al., 1987). Since alkaloids and terpenoids have toxic properties for arthropods (Geissman; Crout, 1969), possibly seedlings of coffee under water deficit could have produced these compounds in greater quantity, contributing to the population decrease of the mite.

Nitrogen content was not influenced by field capacity or presence of the mite, except for the $25 \%$ capacity, which was lower in plants containing mites (Figure 1). Similar result was 
observed by Andrade et al. (2008) who found that the presence of $B$. phoenicis s.l. in citrus plants did not significantly affect the nitrogen concentration of the leaves. On the other hand, Nogueira et al. (1996) found that citrus plants infected with B. phoenicis s.l. presented reduction of leaf nitrogen content. Nitrogen concentration in plants is related to the abundance of pest mites, since the presence of nutrients favors the population of these arthropods (Sudoi; Khaemba; Wanjala, 1996). However, information on the relationship between water availability, leaf nitrogen and the presence of mites is still contradictory, so further investigation is still needed to understand this relationship. In our study, we found that the presence of other factors, such as water availability was more pronounced to favor population increase.

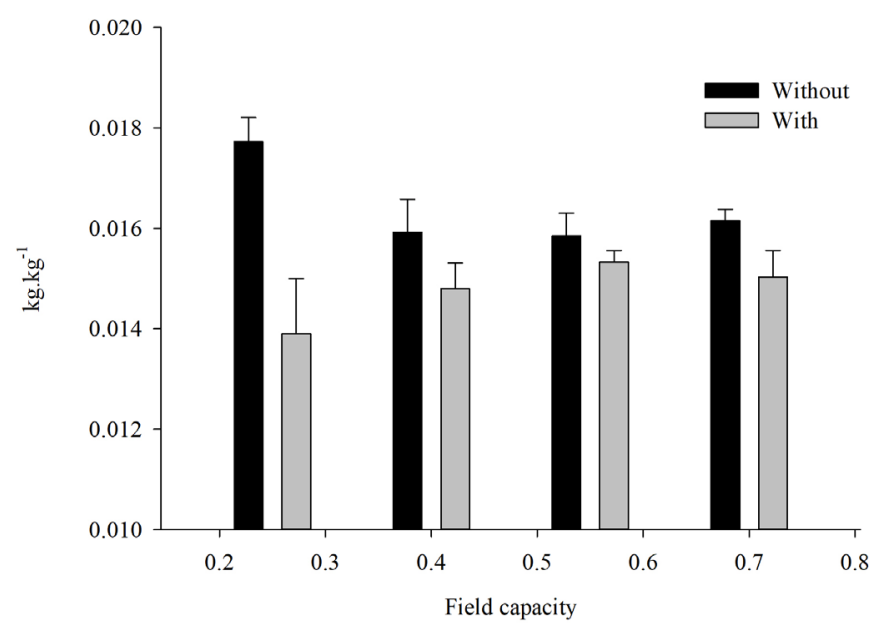

Figure 1: Average nitrogen content in plants maintained at different field capacity and in the presence or absence of viruliferous Brevipalpus yothersi. Asterisk represents difference between treatments at $5 \%$ level by Tukey test.

\section{CONCLUSIONS}

Leaf temperature was influenced by water availability. The presence of viruliferous mites contributed to the rise of DWSI. Water availability influences the mite population, since plants closer to their ideal water conditions favored the population.

\section{ACKNOWLEDGMENTS}

The authors thank the São Paulo Research Foundation (FAPESP grant number 2014/02960-4) for the scholarship provided to the first author. Special thanks to Dr. Elliot Watanabe Kitajima from the Support Center for Electron Microscopy Research Applied to Agriculture (NAP-MEPA) ESALQ/USP for the support provided for confirmation of the mite species.

\section{REFERENCES}

ANDRADE, D. J. et al. Efeito do déficit hídrico e da presença do vírus da leprose dos citros na temperatura foliar e sua relação com a população de Brevipalpus phoenicis e a severidade da doença em plantas cítricas. Laranja, 29(1-2):1-15, 2008.

BARBOSA, D. G. et al. Diversidade de ácaros em aceroleira (Malpighia emarginata) na Universidade Federal Rural de Pernambuco em Recife, PE. Neotropical Entomology, 32(4):577-583, 2003.

\section{BARbosA, J. C.; MALDONADO, J. W. AgroEstat} - sistema para análises estatísticas de ensaios agronômicos. FCAV/UNESP, Jaboticabal, 2015. 396p.

BASTIANEL, M. et al. Citrus leprosis: Centennial of an unusual mite--virus pathosystem. Plant Disease, 94(3):284-292, 2010.

BEARD, J. J. et al. Brevipalpus phoenicis (Geijskes) species complex (Acari: Tenuipalpidae) - a closer look. Zootaxa, 3944(1):1-67, 2015.

BOARI, A. J. Mancha anular do cafeeiro (Coffe ringspot virus - CoRSV). Embrapa Amazônia Oriental, 2011. $45 \mathrm{p}$.

BRANQUINHO, W. G. et al. Doenças que afetam plantios de café e de mandioca no Distrito Federal. Fitopatologia Brasileira, 13(2):140, 1988.

BRISKE, D. D.; CAMP, B. J. Water stress increases alkaloid concentrations in threadleaf groundsel (Senecio longilobus). Weed Science, 30(1):106-108, 1982.

CHABI-JESUS, C. et al. Identification and characterization of citrus chlorotic spot virus, a new dichorhavirus associated with citrus leprosis-like symptoms. Plant Disease, 102(8):1588-1598, 2018.

CHAGAS, C. M. Associação do ácaro Brevipalpus phoenicis (Baker) à mancha anular do cafeeiro. O Biológico, 39:229-232, 1973.

\section{COMPANHIA NACIONAL DE ABASTECIMENTO -} CONAB. Boletim café janeiro. 2019. Available in: $<$ https://www.conab.gov.br/info-agro/safras/cafe $>$. Access in: February, 24, 2019a.

\section{COMPANHIA NACIONAL DE ABASTECIMENTO -} CONAB. Indicadores da agropecuária. 2019. Available in: <https://www.conab.gov.br/info-agro/precos/revistaindicadores-da-agropecuaria. Access in: February, 24, 2019b. 
COSTA, J. M.; GRANT, O. M.; CHAVES, M. M.

Thermography to explore plant-environment interactions. Journal of Experimental Botany, 64(13):3937-3949, 2013.

COSTA, J. O. et al. Physiological responses of coffee tree under different irrigation levels. Engenharia Agrícola, 38(5):648-656, 2018.

CZERMAINSKI, A. B. C. et al. Dinâmica temporal da população do ácaro Brevipalpus phoenicis da leprose dos citros sob condições naturais de epidemia. Fitopatologia Brasileira, 32(4):295-303, 2007.

FADINI, M. A. M.; PALLINI, A.; VENZON, M. Controle de ácaros em sistemas de produção integrada de morango. Ciência Rural, 34(4):1271-1277, 2004.

FERNANDES, E. D.; TURCO, J. E. P. Utilização do índice de estresse hídrico na detecção de estresse hídrico em cultura de soja. Engenharia Agrícola, 23(1):41-52, 2003.

FIGUEIRA, A. R. et al. Vírus da mancha anular do cafeeiro tem causado prejuízos relevantes aos cafeicultores da região do Alto Paranaíba. Fitopatologia Brasileira, 20(1):299, 1995.

\section{FOOD AND AGRICULTURE ORGANIZATION} STATISTICS DIVISION - FAO. FAO statistical database. 2019. Available in: <http://www.fao.org/ faostat $>$. Access in: February, 24, 2019.

FREITAS-ASTÚA, J. et al. Differentially expressed stressrelated genes in the compatible citrus-Citrus leprosis virus interaction. Genetic Molecular Biology, 30(3):980-990, 2007.

GEISSMAN, T. A.; CROUT, D. H. Organic chemistry of secondary plant metabolism. Freeman, San Francisco. 1969. 592p.

GUTIÉRREZ, M. V.; MEINZER, F. C. Carbon isotope discrimination and photosynthetic gas exchange in coffee hedgerows during canopy development. Australian Journal Plant Physiology, 21(2):207-219, 1994.

HÖFT, M.; VERPOORTE, R.; BECK, E. Growth and alkaloid contents in leaves of Tabernaemontana pachysiphon Stapf (Apocynaceae) as influenced by light intensity, water and nutrient supply. Oecologia, 107:160169, 1996.

INTERNATIONAL COFFE ORGANISATION - ICO. Monthly coffee market report - January 2019. Available in: <http://www.ico.org/Market-Report-18-19-e.asp>. Access in: February, 24, 2019.
JACKSON, R. D. Canopy temperature and crop water stress. In: HILLEL, D. (ed) Advances in irrigation. Academic Press, New York, p.43-85, 1982.

KITAJIMA, E. W.; CHAGAS, C. M. Viral diseases of coffee. In: WINTGENS, J. N. (ed.) Coffee: Growing, processing, sustainable production. 2nd ed. Wily-VCH, Wienheim, p.550- 556, 2009.

KITAJIMA, E. W.; RODRIGUES, J. C. V.; FREITASASTÚA, J. An annotated list of ornamentals naturally found infected by Brevipalpus mite-transmitted viruses. Scientia Agricola, 67(3):348-371, 2010.

KRANTZ, G. W.; WALTER, D. E. A. Manual of Acarology. 3rd edn. Texas Tech University Press: Lubbock, Texas. 2009. 807 p.

LOKAR, L. C. et al. Variation in terpene composition of Artemisia alba in relation to environmental conditions. Biochemical Systematics and Ecology, 15(3):327-333, 1987.

MACHADO, E. C. et al. Trocas gasosas e relações hídricas em laranjeiras com clorose variegada dos citros. Revista Brasileira de Fisiologia Vegetal, 6:5357, 1994.

MATTSON, W. J.; HAACK, R. A. The role of drought stress in provoking outbreaks of phytophagous insects. In: BASTIANEL P.; SCHULTZ J. C. (eds) Insect outbreaks. Academic Press, San Diego, p.365-407, 1987.

MEDINA, C. L.; MACHADO, E. C.; PINTO, J. Fotossíntese de laranjeira 'Valência' enxertada sobre quatro portaenxertos e submetida à deficiência hídrica. Bragantia, 57(1):1-14, 1998.

\section{MINISTÉRIO DA AGRICULTURA, PECUÁRIA E} ABASTECIMENTO - MAPA. Café no Brasil. 2018. Available in: < http://www.agricultura.gov.br/assuntos/ politica-agricola/cafe/cafeicultura-brasileira\#section-2>. Access in: February, 24, 2019.

MORAES, F. H. et al. Ocorrência do vírus da pinta verde em maracujá no estado do Maranhão, Brasil. Fitopatologia Brasileira, 31(1):100, 2006.

NOGUEIRA, N. L. et al. Influence of leprosis on the mineral composition of Citrus sinensis leaves. Scientia Agricola, 53(2-3):354-355, 1996.

NOGUEIRA, R. J. M. C. et al. Comportamento fisiológico de duas cultivares de amendoim submetidas a diferentes regimes hídricos. Pesquisa Agropecuária Brasileira, 33(12):1963-1969, 1998. 
NUNES, M. A. et al. Brevipalpus spp. (Acari: Tenuipalpidae) como vetor de Coffee ringspot virus (Dichorhavirus). In: CASTILHO, R. C. et al. Anais do III Congresso Latinoamericano de Acarologia e VI Simpósio Brasileiro de Acarologia, Pirenópolis, Brasil. 2018a. 300p.

NUNES, M. A. et al. First report of Brevipalpus papayensis as vector of Coffee ringspot virus and Citrus leprosis virus C. Plant Disease, 102(5):1046-1046, 2018 b.

OLIVEIRA, C. D. Máquina de varredura de ácaro "Modelo Jaboticabal". Anais da Sociedade Entomológica Brasileira, 12:299-303, 1983.

RAMOS-GONZÁLEZ, P. L. et al. Unveiling the complete genome sequence of clerodendrum chlorotic spot virus, a putative dichorhavirus infecting ornamental plants. Archives of Virology, 163(9):2519-2524, 2018.

RAMOS-GONZÁLEZ, P. L. et al. Phylogenetic and molecular variability studies reveal a new genetic clade of citrus leprosis virus C. Viruses, 8(6):153, 2016.

REIS, P. R.; CHAGAS, S. D. R. Relação entre o ataque do ácaro-plano e da mancha-anular com indicadores da qualidade do café. Ciência e Agrotecnologia, 25(1):72$76,2001$.

RODRIGUES, J. C. V.; NOGUEIRA, N. L. Ocorrência de mancha anular do cafeeiro no estado do Paraná e sobrevivência a geada. Fitopatologia Brasileira, 26(1):115-116, 2001.

RODRIGUES, J. C. V. et al. Occurrence of Coffee ringspot virus, a Brevipalpus miteborne virus in coffee in Costa Rica. Plant Disease, 86(5):564-564, 2002.

ROY, A. et al. Role bending: Complex relationships between viruses, hosts, and vectors related to citrus leprosis, an emerging disease. Phytopathology, 105(7):872-884, 2015.

SUDOI, V.; KHAEMBA, B. M.; WANJALA, F. M. E. Influence of soil nitrogen (NPKS 25:5:5:5) on Brevipalpus phoenicis Geijskes (Acari: Tenuipalpidae) mite incidence and damage symptoms on tea. Annals of Applied Biology, 128(1):13-19, 1996.

WHITE, T. C. R. The abundance of invertebrate herbivores in relation to the availability of nitrogen in stressed food plants. Oecologia, 63:90-105, 1984. 